\title{
Relato De Caso: Parada Cardiorrespiratória Por Choque Elétrico Com Reanimação Cardiopulmonar E Desfibrilação Precoce No Local
}

\author{
Souza, D.L.S.; Barassuol, H.F.; Morais, C.O.; Molinari, V.K.; Laporte, G.A.; \\ Velho, A.V.;
}

Apresentador: Dante Lucas Santos Souza

\section{Resumo}

Introdução: A parada cardiorrespiratória (PCR) corresponde à abrupta perda da função cardíaca. Ocorre devido a um mau funcionamento do sistema cardíaco decorrente, principalmente, de um ritmo cardíaco anormal denominado fibrilação ventricular. Seu prognóstico é variável, podendo ser fatal ou reversível. Objetivo: Evidenciar a importância da reanimação cardiopulmonar (RCP) realizada por leigos e a desfibrilação precoce no paciente vítima de PCR. Metodologia/Relato de Caso: E.C.D. sexo masculino 42 anos operário de construção civil na manhã de 07 de Maio de 2013, enquanto trabalhava, foi vítima de choque elétrico após contato com fio de alta tensão. A corrente teve entrada da região hipotenar esquerda e saída na região calcânea de mesmo lado, levando à perda de consciência e à PCR. Identificada a PCR, foi acionado Serviço de Atendimento Móvel de Urgência (SAMU) através do telefone 192. Durante a ligação, o médico regulador orientou o solicitante a respeito das manobras de RCP, que foram prontamente iniciadas. Após 8 minutos, uma unidade de suporte avançado chegou ao local onde o solicitante prosseguia com a RCP no paciente. Os socorristas constataram fibrilação ventricular no monitor cardíaco e procederam a desfibrilação com dispositivo externo automático (DEA) com a consequente recuperação do paciente após 7 dias de internação. Resultados/Discussão: Sabe-se que a cada minuto que uma vítima de PCR não recebe atendimento a sua chance de sobrevivência cai de 7 a $10 \%$. Por tanto, o seu pronto reconhecimento por qualquer pessoa é primordial para o tratamento. Feito isto, o socorrista deve solicitar ajuda ao SAMU 192. Além de enviar uma ambulância para atendimento da vítima, o médico regulador do SAMU deve orientar o solicitante, por telefone, sobre como realizar a RCP com o uso do DEA quando disponível. Conclusão: O caso relatado ilustra como o início precoce das manobras de RCP, executadas com eficácia e sem pausas, propicia maior índice de sobrevida aos pacientes em PCR. É importante salientar que o rápido deslocamento da equipe de saúde, bem como o treinamento adequado e a presença de um DEA também são variáveis que influenciam a sobrevida do paciente.

\section{Referência:}

Souza, D.L.S.; Barassuol, H.F.; Morais, C.O.; Molinari, V.K.; Laporte, G.A.; Velho, A.V.;. Relato De Caso: Parada Cardiorrespiratória Por Choque Elétrico Com Reanimação Cardiopulmonar E Desfibrilação Precoce No Local. In: II Congresso Brasileiro de Medicina Hospitalar - II CBMH [= Blucher Medical Proceedings, vol.1, num.5] São Paulo: Editora Blucher, 2014. p.91

DOI 10.5151/medpro-II-cbmh-090 